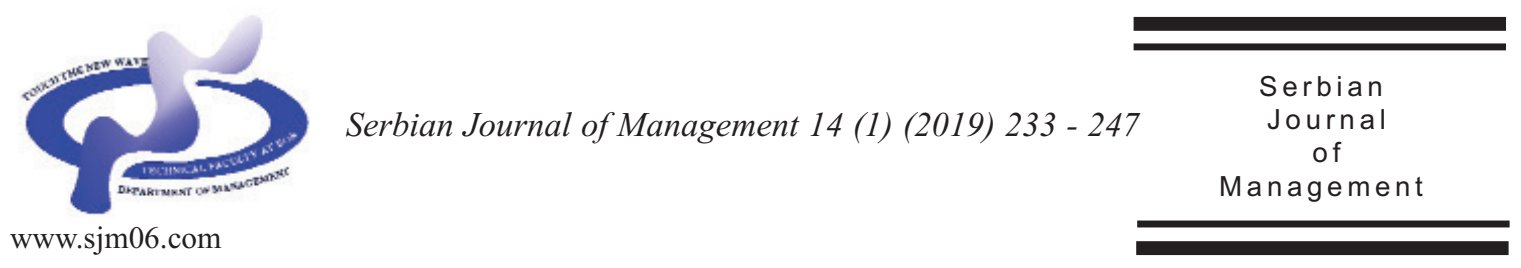

\title{
CHALLENGES IN THE INTRODUCTION OF AGVS IN PRODUCTION LINES: CASE STUDIES IN THE AUTOMOTIVE INDUSTRY
}

\author{
Denisa Hrušecká $^{a^{*}}$, Rui Borges Lopes ${ }^{b}$ and Eva Juřičkováa

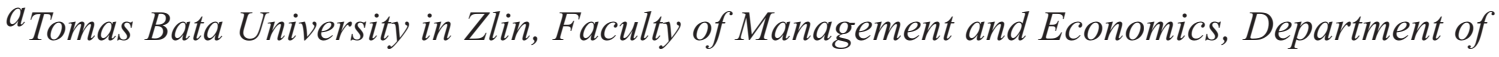 \\ Industrial Engineering and Information Systems, Czech Republic \\ $b_{\text {University of Aveiro, Department of Economics, Management, Industrial Engineering }}$ \\ and Tourism, Portugal
}

(Received 26 June 2018; accepted 20 November 2018)

\begin{abstract}
Increasing customers' requirements together with the current trend of digitization in the spirit of Industry 4.0 puts pressure on manufacturing companies to increase both the flexibility and the performance of their manufacturing and logistic processes. This work presents the challenges in the introduction of AGV (Automatically Guided Vehicles) technology in production lines through two case studies from two different countries, Portugal and the Czech Republic. Both companies are from the automotive industry. Case study research aims to explore and understand complex phenomena. The main purpose of this study is to investigate the limitations and necessary conditions that must be considered when implementing AGV technology for automating selected logistic processes. Based on the data collected through multiple observations, a three-phase methodology considering technological, organizational and safety aspects is proposed as the main output. The basic scheme also includes the proposal of some critical success factors and key performance indicators that should be monitored in order to evaluate the efficiency of implementing this technology in future projects.
\end{abstract}

Keywords: automated guided vehicles, material handling, logistics, case study, logistic performance

\section{INTRODUCTION}

Automated guided vehicles (AGVs) and corresponding systems have been around for some time. In fact, the automation of transportation systems in the production, trade and service sectors is currently considered a critical point when addressing internal logistics optimization (Schulze \& Wullner, 2006). This has led over the years to an increasing interest in such material handling systems in manufacturing and

\footnotetext{
* Corresponding author:hrusecka@fame.utb.cz
}

DOI: $10.5937 /$ sjm14-18064 
assembly companies (Arifin \& Egbelu, 2000). Still, the implementation of these systems is not straightforward, and companies typically face several challenges.

Looking at the literature, often the focus is on the technical characteristics of AGVs and corresponding systems (such as the vehicles' guidance systems, routing optimization or location on the shop floor). From a practical standpoint, although these studies are relevant, they disregard other equally important aspects, such as organizational (e.g. readiness of the production lines, proper logistic flows, etc.) and safety concerns (for employees in production lines or even logistic operators when working simultaneously with AGV systems). As Synáková (2017) confirms, despite decades of development of various advanced manufacturing methods and logistic systems, and advanced systems for production planning and forecasting, the level of interconnection of the various systems is still quite low.

Concerning technical characteristics, the most commonly addressed are those regarding the design and control of the system. Vis' (2006) review of the design and control of AGV systems focuses on research regarding manufacturing, distribution, transshipment and transportation systems. The author concludes that most of the models reviewed (analytical and simulation) are applicable to design problems in manufacturing, advocating the need for further analytical and simulation models for handling large AGV systems. In fact, earlier works (e.g. Vosniakos \& Mamalis, 1990) have already pointed out the potential of simulation in both the design and the evaluation of these systems.

Arifin and Egbelu (2000) propose an analytical model based on a regression technique, which takes into account the characteristics of the facility under analysis to estimate the number of AGVs required. Results suggest that it is a viable alternative to simulation in the initial stage of the system design. Concerning the home location of AGVs in the shop floor, $\mathrm{Hu}$ and Egbelu (2000) use optimization techniques to obtain the location that minimizes the system response time when supplying demand points.

Using simulation, Farling, Mosier and Mahmoodi (2001) tackle a common issue in these systems: congestion. They compare three different configurations with several experimental conditions and conclude that system size, load/unload time and machine failure significantly affect systems' performance. Besides congestion, Ganesharajah, Hall and Sriskandarajah (1998) consider several problems arising in these systems, namely flowpath design, fleet sizing, job and vehicle scheduling, and dispatching. Both simulation and optimization techniques are used to propose solutions to these problems. The authors suggest the development of an integrated approach as they identify inefficiencies resulting from addressing these problems separately. Several studies have used discrete event simulation for testing changes regarding the use of AVGs, being one of the most used tools for that effect. Some of these are the works by Lee, Choi and Khaksar (1990), Kesen and Baykoç (2007) and Um, Cheon and Lee (2009).

Another technological aspect concerns the guidance system used by the vehicles, which according to Schulze and Wullner (2006) initially was mostly using optical or inductive guidelines, and has been gradually shifting to laser guidance. Besides that, Sabattini et al. (2018) point out another 
mandatory step toward deployment of AGV systems in a dynamic production environment: a classification capability enabling high-level decision making to increase performance.

Looking at the works previously reviewed on AGV systems, the findings by Ganesharajah, Hall and Sriskandarajah (1998) are particularly noteworthy; they conclude that inefficiencies result from separately addressing the different aspects/problems of AGV systems. The goal of this work is therefore to look beyond what can be considered technological aspects and equally address the required organizational changes and safety concerns: organizational issues, especially, are often the main causes of lower than expected performance increase. Lazányi (2017) states that successful innovation requires a trusting environment and collaboration. This approach must also be applied in case of process innovations, making interdepartment cooperation another important factor influencing AGV systems implementation. All potential risks in the implementation project and future day-today use of AGVs must be continuously monitored-for example, by the FMEA (Failure Mode Effects Analysis) method, considered by Hrbáčková (2016) the most appropriate from the perspective of recognizing and describing risks.

The remainder of this work is structured in the following way. In Section 2, the methodology used in this work - case study research-is described and the companies under study are presented. Afterwards, in Section 3, the case studies and corresponding main findings are presented, which are discussed in Section 4 in more detail. The last section puts forward the main conclusions of this work.

\section{METHODOLOGY}

In this work the case study method is used to identify the critical success factors (CSFs) for implementation of AGV systems in terms of material handling and the set of key performance indicators (KPIs) for evaluating its efficiency in post-implementation phases. With case study research, the aim is to explore and understand complex phenomena; it is widely used when trying to understand real world events. In operations management, case studies have been widely used, being one of the most powerful research methods and having contributed to the development of many of the concepts and theories in the literature (Voss et al., 2002).

This research comprised the following phases: literature review; data collection; identification of processes being addressed; understanding of existing and new processes; and analysis and interpretation of results. Based on the literature review and data collected through multiple observations, the proposed implementation CSFs are defined with regard to technological, organizational and safety aspects of material handling processes and AGV specifications. Case studies from two automotive tier 2 suppliers from two different countries (Portugal and Czech Republic) are used to investigate the aforementioned challenges. These companies will be named Alpha and Beta for confidentiality reasons.

Company Alpha is one of several factories belonging to a major automotive group. This factory is located in the centre of Portugal in a 300,000 square metre industrial complex. Its assets are valued at nearly 380 million euros, including around 650 machines and 70 robots. The workforce is composed of 1,300 workers, nearly 90 per cent of whom are male. This factory produces two main 
types of component for its group: gearboxes and engine components. Gearboxes represent the largest business volume, although with fewer quantities produced when compared with the engine components (10 million vs 38 million since the factory was established). Alpha exports all of its production to the automotive group's other factories throughout the world, and every car produced by the group has at least one part originating from this factory.

Company Beta is one of the several Czech manufacturing plants of a tier 2 automotive supplier company with its headquarters in Germany. Production facilities cover around 76,000 square meters and employees number more than 2,000 people. Its turnover is around 700 million euros. Production processes include moulding, welding, varnishing and assembling. Assembly lines occupy more than half of the production facilities; they are operated by tugger trains with a driver. Company Beta invests huge amounts of financial resources into the digitization of production and logistic processes every year. Replacing the majority of standard men-driven tugger trains with $\mathrm{AGV}$ technologies is one of its first goals.

\section{CASE STUDIES}

The following subsections detail the two case studies under analysis in this work. They were conducted in automotive supplier companies in two different countries, Portugal and the Czech Republic.

\subsection{Case study I: Portuguese gearbox and engine factory}

The first case study concerns Company Alpha, which, as stated previously, is a Portuguese factory and part of a major automotive group. More specifically, the focus will be on the company's goal of automating the supply and collection of materials to and from assembly lines. At the assembly lines under analysis, three types of vehicle handle the logistics activities: forklifts, man-operated tugger trains and AGVs. An example of these can be seen in Figure 1.

The forklift is gradually being less used, mostly due to safety concerns; however, it is still useful for reaching higher shelves and for carrying heavier material. The manoperated tugger train is currently the most used means of transportation for supplying and collecting material from the assembly

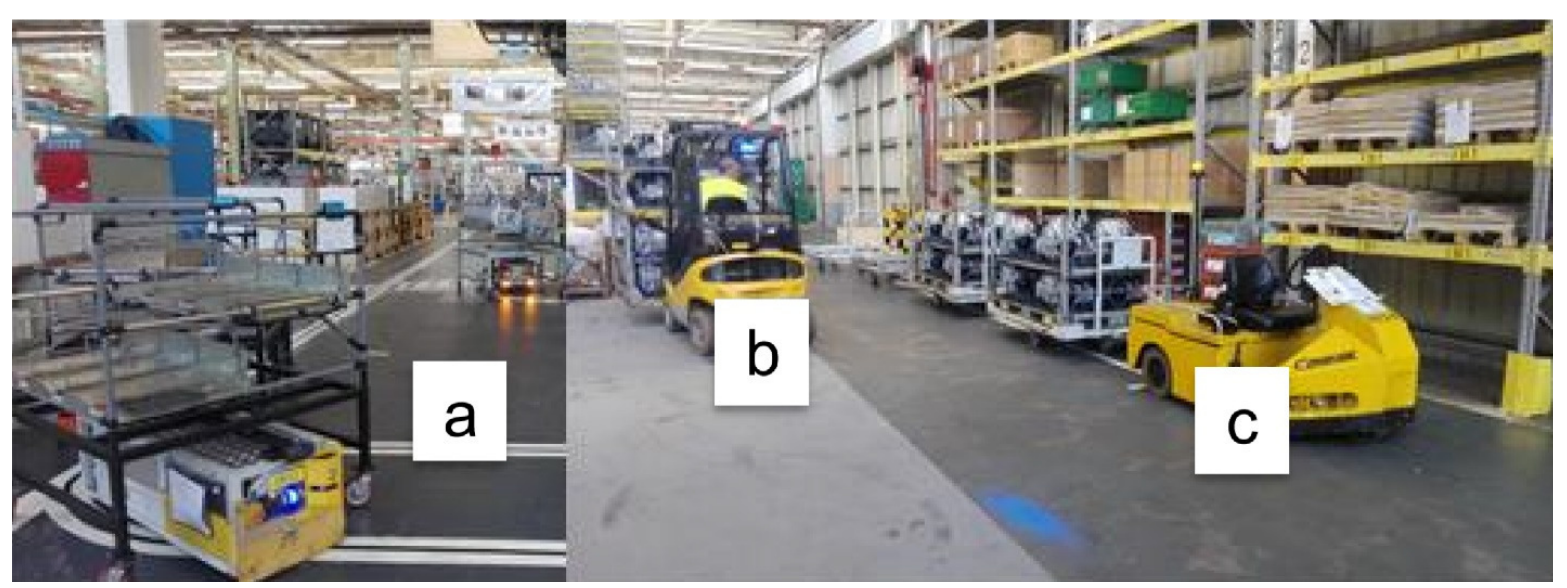

Figure 1. The three types of vehicle operating in Alpha: a) forklift; b) man-operated tugger train; c) AGV 
lines. The AGV is the most recent type of vehicle introduced to the company; it uses an optical guidance system. The vehicle has been receiving increased attention from management as it allows more flexibility in case of increase in production and considerably reduces the risk of work accidents. This has led management to propose and develop a plan to introduce more AGVs in logistics, detailed as follows.

Firstly, current routes were analysed, where several main logistic flows were identified: (1) picking; (2) kanban; (3) parts coming from companies outside the group (POG); (4) finished products; (5) a specific type of supplier; and (6) preparation. Concerning these flows, two were already performed by AGVs.

Based on this, the desired changes to the logistic flows were defined:

- Replace all man-operated tugger trains with AGVs.

- Reduce the number of logistic operators per working shift from three to two.

- $\quad$ Reallocate a storage area to be closer to the assembly lines.

- Ensure the system can reliably support an increase of 15 per cent in production throughput.

- Ensure the system has a secondary (or backup) mode, enabling rollback to it, and continue the scheduled production in case of problems with AGVs.

The first aspect considered was the choice of AGV and rolling bases to be used. The rolling bases are to be towed and the AGV must have a towing capacity of $1200 \mathrm{~kg}$, corresponding to a maximum of two rolling bases. The maximum allowed speed of the $\mathrm{AGV}$ is 35 metres per minute $(2.1 \mathrm{~km} / \mathrm{h})$ in order to comply with the group's safety regulations. Moreover, the AGV should have sensors to prevent collisions and the ability to know its position in real time (to have online information regarding the AGV). Magnetic strips were chosen instead of optical reading, because forklifts also use the same corridors, causing significant damage to the black lines and often causing the AGVs to stop due to less clear or interrupted lines. Each of the two assembly lines would have its own set of AGVs, three per line, and a backup AGV would always be ready in case of any problem with the existing ones. An example of the chosen AGV is shown in Figure 2a).

Several types of rolling base were currently supplying the assembly lines, w the difference between them being the size of the packages they could safely carry. To try to make the rolling bases uniform, a new rolling base was developed with the possibility to adapt the supports to different types of packaging (see Figure 2b). Man-operated tugger trains can also use these rolling bases.

The focus was then on organizational aspects, such as defining the home location of the AGVs, and new loading and unloading areas for the main logistic flows. The area previously in use as the home location of the AGVs was some distance from the assembly lines. As the AGV has a lower speed than the man-operated tugger trains, two extra AGVs would have been needed to maintain the same supply activities if the home location stayed the same. Another issue is that it would become a segment with increased traffic, as AGVs, man-operated tugger trains and forklifts would be converging into that area. Additionally, the loading/unloading area required extra space for the AGV's manoeuvres.

Therefore, the proposed solution was to combine the home location and loading/unloading area in a different location 
that would not impact the existing main flows. The area chosen was where there were some shelves for low-consumption items. This new area would allow the reduction of traffic flow regarding expedition, reducing the distance AGVs would have to traverse and, consequently, the number of required AGVs. The new area where the shelves would be removed is the previous home location of the AGVs. The biggest drawback of this new location is that it will be impossible to move large machines into the section.

Additionally, following the aforementioned changes, a new logistic flow was proposed. In terms of distances to be traversed, a significant gain could be observed, reducing previous routes from $400 \mathrm{~m}$ to $260 \mathrm{~m}$ (35 per cent reduction). Moreover, it resulted in less traffic near the expedition area (loading bay). A new continuous flow was also designed for the assembly lines, allowing the operator to the have the rolling bases in the required position (thus making sure he does not need to perform unnecessary movements to place the rolling bases in the correct location). A new procedure for handling the materials was also designed and provided to the lines' operators.

These proposed changes were tested using discrete event simulation, as most of the literature suggests. Both the current scenario and the future proposed scenario (corresponding to the desired increase in production) were tested, with three different alternatives, using different numbers of AGVs.

A financial analysis was then performed, showing the expected return on investment to occur in 1.4 years. This would be accomplished taking into account the expected savings resulting from having three fewer logistic operators and two manoperated tugger trains. To replace them, six new AGVs, 12 new bases and the automation system would have to acquired. Additionally, the proposed changes would allow improving the companies' KPI concerning logistics performance, thus further strengthening its position among the best performers in the automotive group.

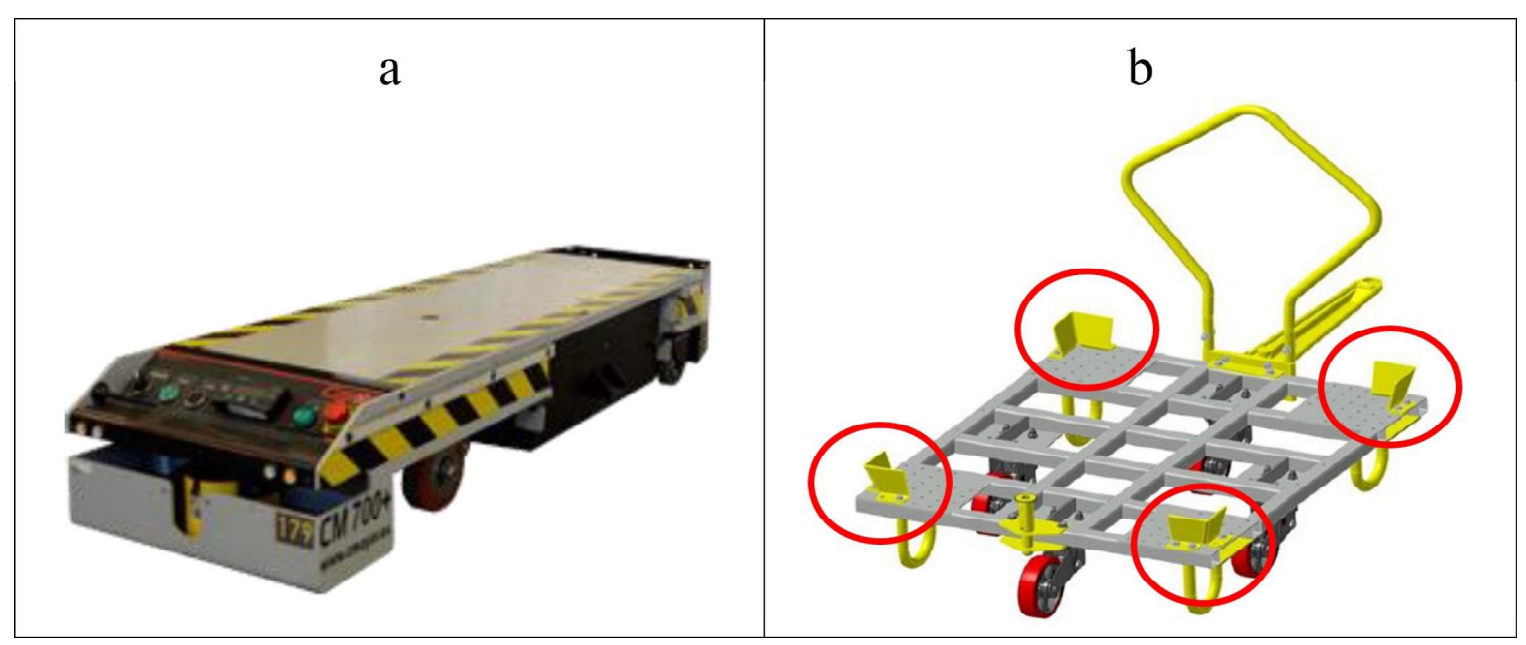

Figure 2. a) Chosen AGV; b) rolling bases to be used (capable of adapting the supports to different types of packaging, highlighted with red circles) 
3.2. Case study II: Czech plant of foreign automotive company

The second case study was conducted in the Czech plant of a tier 2 automotive supplier company. The main goal was to propose a pilot project to implement AGVs for the transportation of final products from assembly lines to the dispatch warehouse. The target area had been operated by mandriven tugger trains and the company decided to replace some routes with automated tugger trains (AGVs).

In the first step, the most appropriate route/circuit was discussed in order to avoid the most frequent crossroads and alleys. A heat map of the whole shop floor was made for this purpose. After that, the available AGV types were examined to find the one meeting the specifications of the factory at the highest level. More specifically, (i) the loading capacities and speeds of vehicles were compared with the frequency of orders coming from assembly lines; (ii) tugger train dimensions were compared with the dimensions of alleys and curves, taking into account the extra space necessary for AGV manoeuvres; (iii) the type of navigation technology was compared with the possibilities of the shop floor; and (iv) automatic load transfer was taken into account for the future extension of AGVs use for material handling.

The next aspect considered was the type of rolling base used with the AGV tugger train. As the company uses so-called Eframes (see Figure 3), which are very efficient for material handling, our proposal took this fact into account and we maintained this type of cart for the AGV solution.

In the final step, the AGV implementation proposal itself was made. The target circuit included six stops with different outputs (boxes per hour). Using both observations and statistical data from the ERP system, the average outputs in boxes per hour were obtained (shown in Table 1).

Because of the maximum loading capacity of the AGV tugger train, the whole circuit must be divided into two parts. The

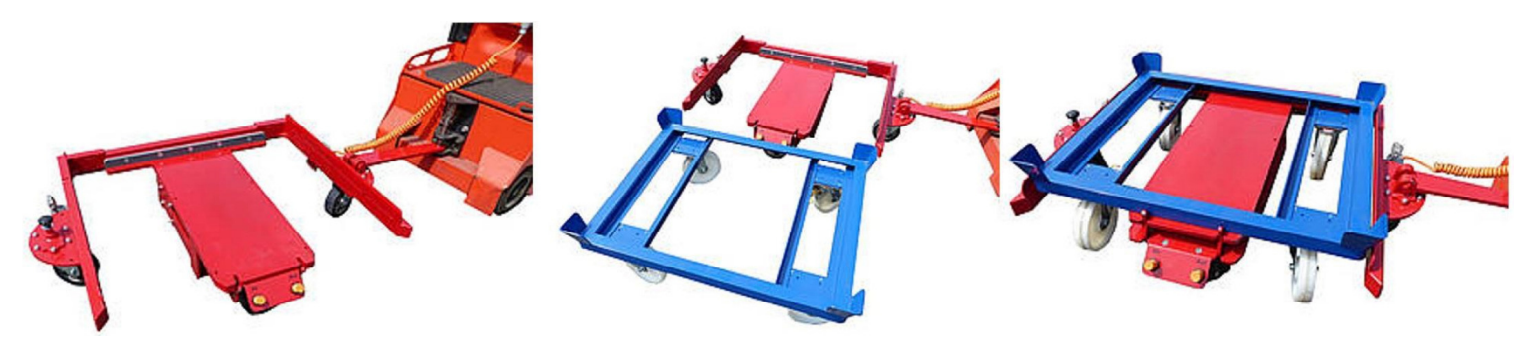

Figure 3. Examples of E-frames (Rollcart Transport System, 2018)

Table 1. Outputs of assembling lines (modified according to Damašková et al., 2017)

\begin{tabular}{ccc}
\hline Workstation/Stop & Output per hour & Circuit \\
\hline 1 & 3 & $\mathrm{~A}$ \\
2 & 10 & $\mathrm{~A}$ \\
3 & 5 & $\mathrm{~B}$ \\
4 & 14 & $\mathrm{~A}$ \\
5 & 12 & $\mathrm{~B}$ \\
6 & 1 & $\mathrm{~B}$ \\
\hline
\end{tabular}


positions of the output areas of each assembly line (left/right side) were chosen as the most suitable criteria for this division (Table 2, Circuits A and B). Each circuit must be operated by two AGV trains in order to be able to pick up all outputs on time (maximum loading capacity is four pallets). Schedules of all AGV trains were planned in a way such that waiting at crossroads or in narrow one-way alleys was eliminated. Table 2 shows an example of the schedules for circuits $\mathrm{A}$ and $\mathrm{B}$, where each circuit is operated by two AVGs in several different cycles $(\mathrm{C} 1, \mathrm{C} 2$, etc.).
The automated unloading of empty pallets and loading of full pallets near production lines was addressed afterwards. In order to save time, unloading and loading should be done simultaneously (amounting to a total of six seconds), which was ensured by a strict standard in respect of placing unloading/loading areas near assembly lines (see Figure 4).

To sum up, the following organizational, technological and safety aspects were considered in order to reach the set goals: the traffic frequency of individual crossroads and alleys, dimensions of alleys and curves,

Table 2. Proposed schedules (modified according to Damašková et al., 2017)

\begin{tabular}{|c|c|c|c|c|c|c|c|c|c|c|c|c|c|}
\hline \multirow{3}{*}{ Stop } & \multicolumn{5}{|c|}{ Circuit A } & \multicolumn{8}{|c|}{ Circuit B } \\
\hline & \multicolumn{3}{|c|}{ AGV 1} & \multicolumn{2}{|c|}{ AGV 2} & & \multicolumn{3}{|c|}{ AGV 1} & \multicolumn{4}{|c|}{ AGV 2} \\
\hline & C1 & $\mathrm{C} 2$ & $\mathrm{C3}$ & C1 & $\mathrm{C} 2$ & C1 & $\mathrm{C} 2$ & $\mathbf{C 3}$ & $\mathrm{C} 4$ & C1 & $\mathrm{C} 2$ & C3 & $\mathrm{C} 4$ \\
\hline 1 & & & & & & & 2 & & 1 & & & & \\
\hline 2 & & & & & & & 2 & & 3 & 3 & & 4 & \\
\hline 3 & & & 2 & 3 & & & & & & & & & \\
\hline 4 & & & & & & 3 & & 4 & & & 3 & & 4 \\
\hline 5 & 4 & 4 & & & 4 & & & & & & & & \\
\hline 6 & & & 1 & & & & & & & & & & \\
\hline$\Sigma$ & 4 & 4 & 3 & 3 & 4 & 3 & 4 & 4 & 4 & 3 & 3 & 4 & 4 \\
\hline
\end{tabular}

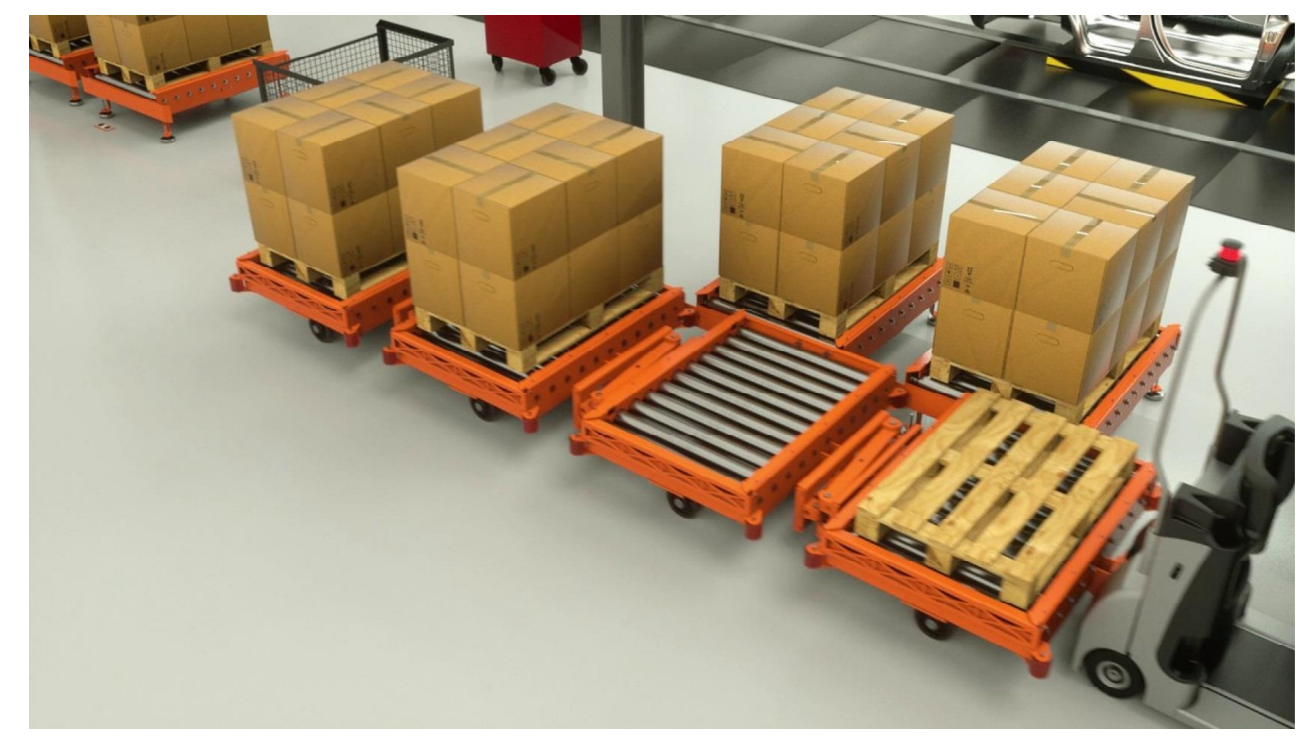

Figure 4. Example of a process ensuring automated and efficient unloading/loading activities near production lines (LR Intralogistik, 2017) 
and space for AGV manoeuvres, frequency of orders, hourly outputs of production lines, vehicle parameters: speed, loading capacity, type of navigation, placement of output areas of production lines, order fluctuations (for interconnection with lines through BAR codes), the length of one circuit in metres and seconds, loading and unloading possibilities (on floor, higher, automated lift, etc.), ergonomic aspects of manual handling with rolling bases/pallets, supplying lines with empty pallets (reverse material flow, how to organize), plans for solving unpredictable situations (forklifts or manual handling), type of guidance system, sensors to prevent collisions, possibility of manual operation of AGV tugger train in case of need.

Expected savings result especially from reducing the number of logistic operators by four people, because four man-operated tugger trains will be replaced by new AGVs. The financial analysis performed assumes an expected return on investment in less than one year. This rapid return rate is influenced by the fact that it will not be necessary to replace the rolling bases and E-frames currently used.

\section{FRAMEWORK AND DISCUSSION}

Based on these case studies, a common framework is proposed, encompassing the cases' main steps, and possibly equally suitable for addressing the incorporation of AGVs in other industrial environments. These main steps are grouped according to the stage within which they have to be considered, namely pre-implementation, implementation, post-implementation, and improvement and maintenance. Figure 5 shows these steps and its grouping.

Firstly, it is important to meet with management and with the workers affected by the change on the shop floor. This

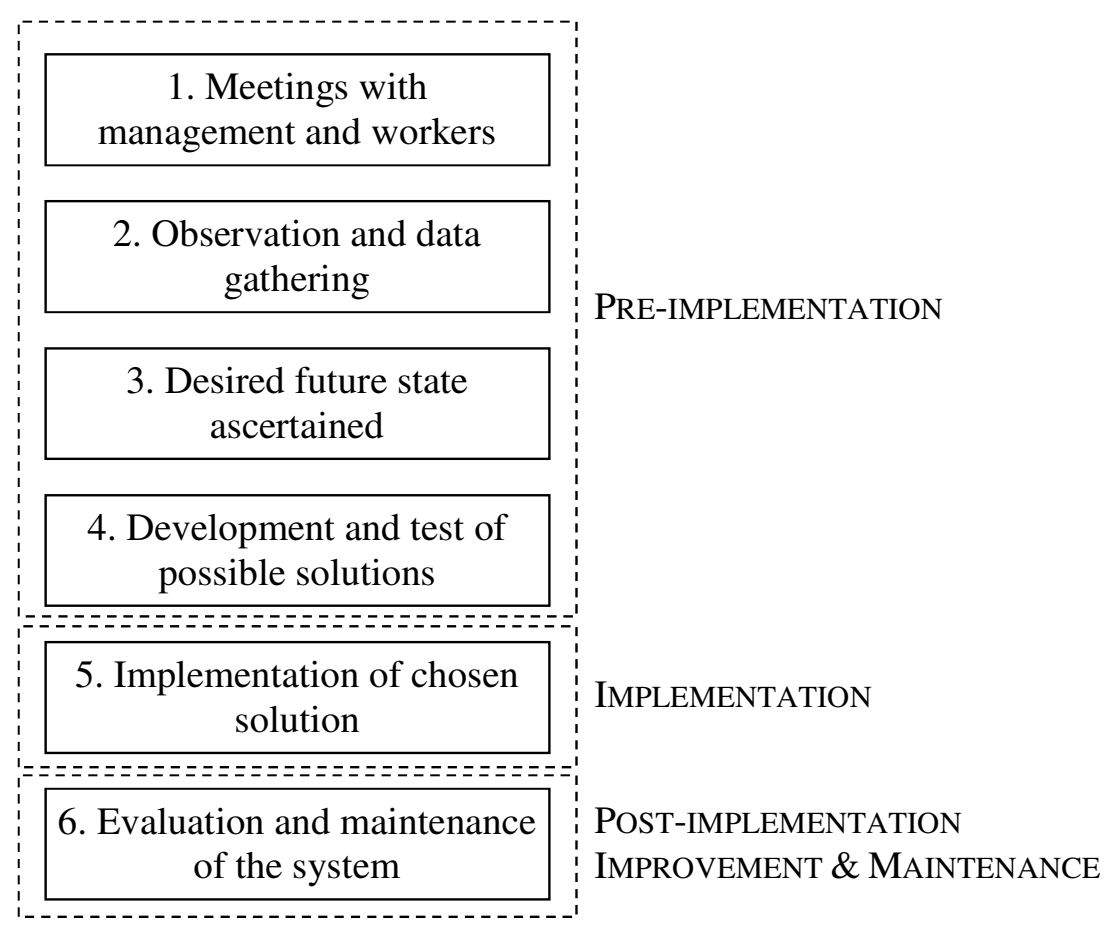

Figure 5. Framework demonstrating the case studies' main steps 
preliminary meeting is crucial to get a feel of the expectations and worries of the main actors involved in the change and to ensure there is motivation for the project. Observation and data gathering will then allow, among other aspects, analysis of the main routes currently being used, determination of occupation rates for the paths on the shop floor, and gathering of information about available technology (e.g. AGVs' main characteristics).

Having gained a more in-depth knowledge of the current situation on the shop floor, the management should establish the main objectives behind the change and provide clear indications concerning the desired future state. Possible solutions must then be developed and tested. These solutions should focus on relevant implementation aspects, such as choice of suitable technology (AGVs and rolling bases); definition of locations for loading and unloading areas; and definition of routes to be used by the AGV and corresponding flows. Afterwards, each of these solutions must be tested in terms of its operational feasibility (typically using discrete event simulation) and be complemented by a financial analysis of the proposed changes.

Finally, implementation and subsequent steps regarding the chosen solution must account for backup/roll-back plans; the system should be continuously evaluated with regard to important KPIs and acted upon when corrective measures are required. Both presented case studies lead to the conclusion that the main CSFs of AGV implementation can be divided into three groups: technological, organizational and safety. All of these should be considered in the pre-implementation phase. However, there are other phases which are equally important. Many other similar projects confirm that setting relevant KPIs or precise and systematic risk management are other unavoidable aspects affecting not only the success of one AGV deployment project, but the future processes operated by this technology.

When defining CSFs and KPIs, we focused our attention only on the main critical issues in order to provide a simple and functional methodology applicable in different types of industrial environment. Especially in case of KPIs, it is not very efficient to have a huge set of indicators. As Rob O'Byrne (2017) says, "A KPI is a metric... but not just any metric. A KPI is a metric focused on a KEY element of business, departmental, or team performance". In line with this statement, too many KPIs can cause a state of confusion and it is not realistic to expect anyone to monitor them on a daily or weekly basis. Instead of having too many indicators, companies should carefully track the most vital elements of performance. We followed this rule and for this reason, the suggested set of KPIs is divided into three crucial groups which respect the main logistics goals triangle of quality, time and cost of delivery: delivery in time, delivery in full and costs of material handling. Adding to these KPIs, we suggest the use of ergonomic, wellbeing and other qualitative indicators.

When considering the implementation of AGVs, the abovementioned CSFs must be set and carefully managed in the first, preimplementation step. Because our study deals with the CSFs connected with a final control loop in order to increase the performance of all future implementation projects, we paid close attention especially to the first and third steps, where individual CSFs and KPIs are set, specified, analysed and monitored (Figure 6). 
The following Table 3 includes some However, these positive effects are specific examples of CSFs and KPIs that were observed. achievable only when all phases of AGV deployment are seriously considered.

As both of our case studies have proved, Financial analysis is the most important tool the return on investment of replacing man- for understanding the viability of the project driven logistic vehicles by AGVs is quite and it cannot be processed without having short, in both cases less than two years. appropriate data-precisely analysed and

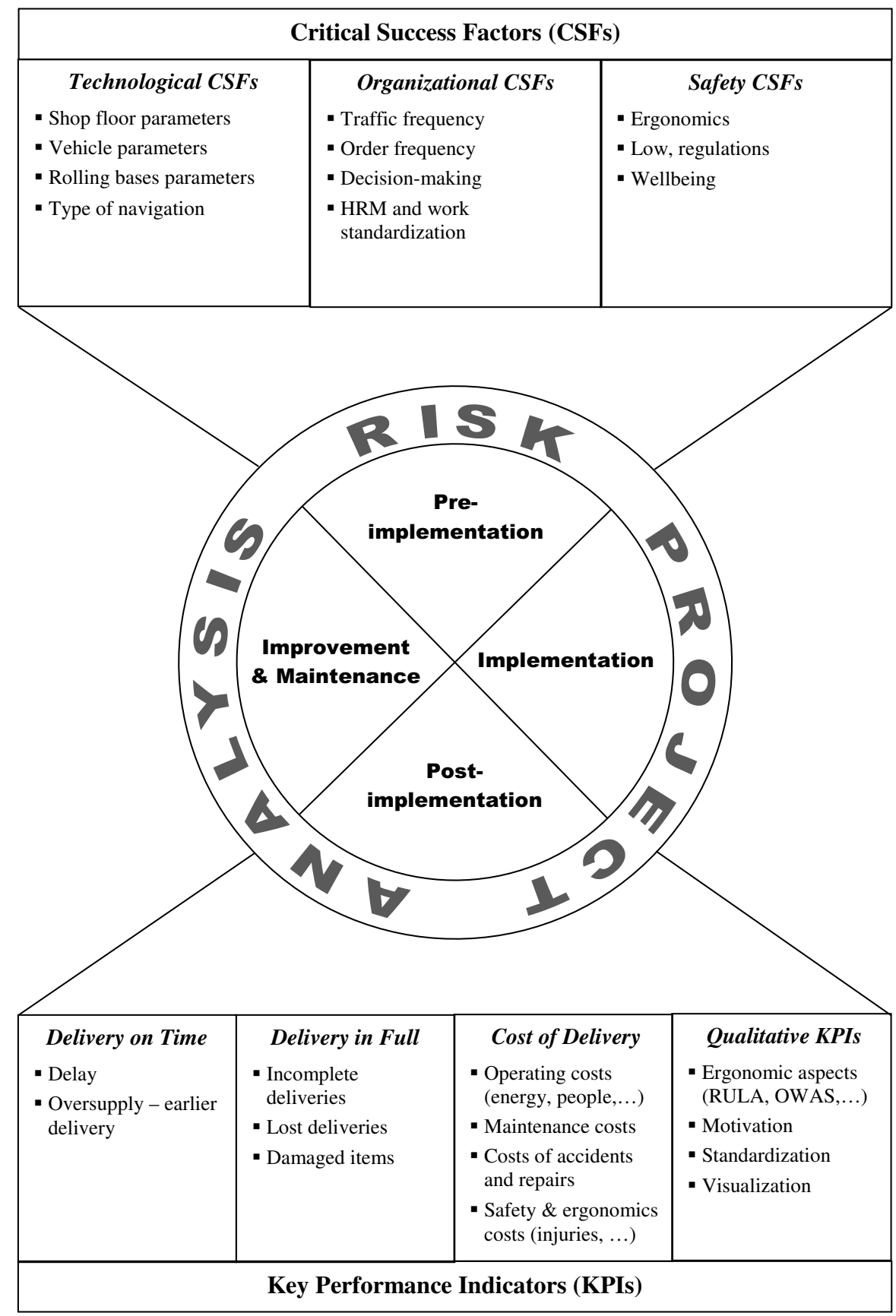

Figure 6. Model of CSFs and KPIs for AGV implementation 
Table 3. Basic Scheme of CSFs and KPIS

\begin{tabular}{lc}
\hline \multicolumn{1}{c}{ CSFs } & KPIs \\
\hline Technological & Delivery on time \\
Dimensions of alleys and curves & $\%$ of delayed deliveries \\
Towing capacity & $\varnothing$ delivery time \\
Types of rolling base & \\
Possible man-driven vehicle & Delivery in full \\
Maximum speed & $\%$ of non-completed orders \\
Sensors to prevent collisions & $\%$ of lost orders \\
Ability to know the position of AGVs & $\%$ of orders delivered to other places \\
in real time & \\
Guidance system & Costs of material handling \\
Space for AGV manoeuvres & $\varnothing$ energy consumption \\
& $\varnothing$ maintenance costs \\
Organizational & $\varnothing$ costs of fixing broken vehicles \\
Traffic frequency (heat map) & $\varnothing$ costs of safety accidents \\
Frequency of orders & \\
Decision-making aspects & Qualitative indicators \\
Work standardization & Level of fulfilling ergonomic \\
HRM, understanding and respecting & requirements based on methods like \\
of set rules, training people & OWAS, NIOSH, RULA, etc. \\
& Motivation of workers \\
Ergonomic aspects & Self-empowerment level of workers \\
Maximum weight of handled units & General organization of workplaces \\
Maximum allowed speed & Visualization standards \\
Wellbeing & Understandable work standards \\
& \\
&
\end{tabular}

evaluated CSFs and possibility of the company fulfilling them, and measured (or estimated) KPIs.

\section{CONCLUSIONS}

From the presented case studies focused on automating the supply and collection of materials to and/or from assembly lines, one can conclude that $\mathrm{AGV}$ technologies provide a great solution to increase the performance of corresponding logistic processes in case of respecting several rules and a common methodology. Kodym, Sedlacek and Kavka (2016) highlight the need to process a large amount of data in order to design and understand selected logistic processes, and model testing to find the best alternative that fulfils the set goals. There is no doubt that this statement is correct, and our proposal takes into consideration all factors that can critically influence the performance of implemented AGV technology. Set KPIs then enable the company to get some kind of feedback in order to make improvements.

Based on this approach, the presented methodology was divided into several steps and the most important categories of CSFs and KPIs were defined for the individual implementation phases. This approach was not deeply described by researchers before and it can help practitioners to avoid serious mistakes and prepare their operations for 
AGV implementation properly. AGV before and it creates a basis for future technology is very helpful, but not sufficient research in the area of SMART logistics in condition for logistic operations the spirit of Industry 4.0.

improvement. Proposed set of CSFs includes all necessary conditions that must be fulfilled before $\mathrm{AGV}$ implementation in order to avoid future problems. After that, during the AGV operation, the performance must be also monitored through predefined KPIs in order to achieve operational objectives under all conditions.

It is evident, but not yet proved, that all CSFs from the pre-implementation and implementation phases influence the values of process KPIs. Determination of relations between individual implementation CSFs and KPIs for AGV systems in the material handling area is the main challenge for our future research. This complex combined $\mathrm{CSF} / \mathrm{KPI}$ methodology was not presented

\title{
Acknowledgement
}

This contribution is one of the results of the RVO projects realized by Faculty of Management and Economics, Tomas Bata University, Zlín, Czech Republic: Development of complexly methodology of process planning, management and organization by implementation and utilization of INDUSTRY 4.0 concept in SMEs and Digital transformation and its influence on customer's behaviour and business processes in the area of traditional and online markets.

\section{ИЗАЗОВИ УВОЪЕЊЕА “АGVS-а" У ПРОИЗВОДНИМ ЛИНИЈАМА: СТУДИЈЕ СЛУЧАЈА АУТОМОБИЛСКЕ ИНДУСТРИЈЕ}

\section{Denisa Hrušecká, Rui Borges Lopes, Eva Juřičková}

\begin{abstract}
Извод
Повећање потреба клијената заједно са тренутним трендом дигитализације у духу Индустрије 4.0 ставља притисак на производне компаније да повећају истовремено и флексибилност и перформансе својих производних и логистичких процеса. Овај рад представља изазове у увођењу “AGV” (аутоматизовано управљање возилом) технологије у производне линије, кроз две студије случаја из двеју различитих земаља, Португалије и Чешке. Обе компаније су из аутомобилске индустрије. Главни циљ ове студије случаја је истражити и разумети сложене појаве ових процеса. Основна сврха ове студије је да истражи ограничења и неопходне услове који се морају узети у обзир приликом примене "AGV" технологије за аутоматизацију одабраних логистичких процеса. На основу података прикупљених кроз вишеструка опажања, предложена је трофазна методологија која разматра технолошке, организационе и сигурносне аспекте. Основна шема укључује и предлог неких критичних фактора успеха и кључних показатеља успешности које треба пратити како би се оциенила ефикасност примене ове технике у будућим пројектима.
\end{abstract}

Кључне речи: аутоматизовано управљање возилом, руковање материјалом, логистика, студија случаја, логистичке перформансе 


\section{References}

Arifin, R., \& Egbelu, P. (2000). Determination of vehicle requirements in automated guided vehicle systems: A statistical approach. Production Planning \& Control, 11 (3), 258-270.

Damašková, G., Nedjalkov, L., Novotný, J., \& Vierik, J. (2017). Implementation of $\mathrm{AGV}$ as a pilot logistic project in selected company. Logistic course - seminar work. Zlín, Czech Republic: TBU in Zlín.

Farling, B.E., Mosier, C.T., \& Mahmoodi, F. (2001). Analysis of automated guided vehicle configurations in flexible manufacturing systems. International Journal of Production Research, 39 (18), 4239-4260.

Ganesharajah, T., Hall, N.G., \& Sriskandarajah, C. (1998). Design and operational issues in AGV-served manufacturing systems. Annals of Operations Research, 76, 109-154.

Hrbáčková, L. (2016). Risk-based thinking in the production process using the Methods of Quality Assurance Matrix and the FMEA process. Journal of System Integration, 7 (1), 1-28.

$\mathrm{Hu}$, C.H., \& Egbelu, P.J. (2000). A framework for the selection of idle vehicle home locations in an automated guided vehicle system. International Journal of Production Research, 38 (3), 543-562.

Kesen, S.E., \& Baykoç, O.F. (2007). Simulation of automated guided vehicle (AGV) systems based on just-in-time (JIT) philosophy in a job-shop environment. Simulation Modelling Practice and Theory, 15 (3), 272-284.

Kodym, O., Sedlacek, M., \& Kavka, L. (2016). Information support for logistic modelling. Proceedings of the 2016 17th International Carpathian Control Conference. ICCC 2016, 335-340.
Lazányi, K. (2017). Innovation: The role of trust. Serbian Journal of Management, 12 (2), 331-344.

Lee, J., Choi, R., \& Khaksar, M. (1990). Evaluation of automated guided vehicle systems by simulation. Computers \& Industrial Engineering, 19 (1-4), 318-321.

LR Intralogistik. (2017, May 10). Automatisierter Routenzug mit dem Still LiftRunner ${ }^{\circledR}$ [Video file]. Retrieved from https://www.youtube.com/watch? $\mathrm{v}=\mathrm{L} 0 \mathrm{gIUHnB} 8 \mathrm{qs}$

O’Byrne, R. (2017). KPI Key performance indicators in supply chain \& logistics. Logistics Bureau, Oct 31. Retrieved from: https://www.logisticsbureau.com/kpi-keyperformance-indicator/

Rollcart Transport System. (2018). Routenzug E-frame. Retrieved from https://rollcart. de/logistikoptimierung/eframe-routenzug/

Sabattini, L., et al. (2018). The PANRobots Project: Advanced automated guided vehicle systems for industrial logistics. IEEE Robotics \& Automation Magazine, 25 (1), 55-64.

Schulze, L., \& Wullner, A. (2006). The approach of automated guided vehicle systems. Proceedings of 2006 IEEE International Conference on Service Operations and Logistics, and Informatics (SOLI), Shanghai, China, 522-527.

Synáková, L. (2017). Production smoothing and cost performance in a production-inventory system. Journal of Competitiveness, 9 (1), 117-133.

Um, I., Cheon, H., \& Lee, H. (2009). The simulation design and analysis of a flexible manufacturing system with automated guided vehicle system. Journal of Manufacturing Systems, 28 (4), 115-122.

Vis, I. (2006). Survey of research in the 
design and control of automated guided vehicle systems. European Journal of Operational Research, 170 (3), 677-709.

Vosniakos, G.C., \& Mamalis, A.G. (1990). Automated guided vehicle system design for FMS applications. International Journal of Machine Tools and Manufacture, 30 (1), 85-97.

Voss, C., Tsikriktsis, N., \& Frohlich, M. (2002). Case research in operations management. International Journal of Operations \& Production Management, 22 (2), 195-219. 